\title{
Impact of humanistic training on the tourism future professional
}

\section{Impacto de la Formación Humanística en el Futuro Profesional del Turismo}

\author{
Jorge Tanyara Sánchez. ${ }^{1}$, Bisleivys Jiménez Valero. ${ }^{2}$, Caridad Alina Jorge Ali. ${ }^{3}$ \& \\ Efrain Velastegui Lopez. ${ }^{4}$
}

\begin{abstract}
DOI: https://doi.org/10.33262/cienciadigital.v5i4.1903

In the Cuban university context, an essential goal is to guarantee an education, which propitiates the development of the knowledge, abilities, capacities and values that contribute to the technological scientific achievements 'implementation, in order to apply them at social scale. This human development is not just an objective from university, it also responds to one of the 2030 Agenda, where the equity and the social justice should be enhanced. It's necessary to foment the sustainable development guaranteeing an economic, ecological and sociocultural balance achieving the territorial autonomy, where the tourism plays a main role. That's why, the main goal of the scientific research is to

\footnotetext{
${ }^{1}$ Prof. Instructor del Departamento de Turismo de la Facultad de Ciencias Empresariales de la Universidad de Matanzas, Cuba. Organismo: Ministerio de Educación Superior. Código Postal: 40100. Correo electrónico: tanyarasanchez93@gmail.com; tanyara.sanchez@umcc.cu. Orcid: https://orcid.org/00000001-7858-1456.

${ }^{2}$ Prof. Titular del Departamento de Turismo de la Facultad de Ciencias Empresariales de la Universidad de Matanzas, Cuba; bisleivys.jimenez@umcc.cu. Código Postal: 40100. Orcid: https://orcid.org/0000-00034812-4558.

${ }^{3}$ Prof. Asistente de la Sede Universitaria Ramal del INDER, La Habana, Cuba. Organismo: Ministerio de Educación Superior e INDER (Instituto Nacional de Deporte, Educación Física y Recreación). Código Postal: 10800. Correo electrónico: alinajorgeali@yahoo.com. Orcid: https://orcid.org/0000-0002-34156164.

${ }^{4}$ Universidad Técnica de Babahoyo, Facultad de Ciencias de la Educación, Los Ríos, Babahoyo, evelasteguil@utb.edu.ec, ORCID https://orcid.org/0000-0002-7353-5853
} 
demonstrate the impact of humanistic training in the development of the tourism career for the achievement of sustainable economic and social development. It was used theoretical methods such as: the analytic-synthetic one, induction-deduction and historical-logical one. It was also used empiric methods such as: the analysis and documental revision, the search, selection of information and the observation. As result, it is obtained methodological preparation actions for Tourism career 'professors, in order they can guarantee a graduate able to apply sustainable management.

Keywords: humanistic training impact, 2030 agenda for sustainable development, methodological teacher training, tourism career disciplines.

\section{Resumen}

En el contexto de la universidad cubana, un objetivo es garantizar una educación que propicie el desarrollo del conocimiento, habilidades, capacidades y valores que contribuyan a la implementación de los resultados científicos tecnológicos, a escala social. Este desarrollo humano no es solo objetivo de la universidad, responde a uno de la Agenda 2030, donde la equidad y la justicia social deben ser potenciadas. Se hace necesario fomentar un desarrollo sostenible garantizando un equilibrio económico, medioambiental y sociocultural, una adecuada autonomía territorial, en ello el turismo juega un rol fundamental. Se declara como objetivo de la investigación científica: demostrar el impacto de la formación humanística en el graduado de la carrera de turismo para el logro del desarrollo económico y social sostenible. Se emplearon de los métodos teóricos el analítico-sintético, inducción-deducción; histórico-lógico y de los métodos empíricos el análisis y revisión documental, la búsqueda, selección de información, y la observación. Se obtiene como resultado acciones de preparación metodológica a egresados que se desempeñan como profesores de la carrera de Turismo para que garanticen un egresado capaz de aplicar una gestión sostenible.

Palabras claves: impacto de la formación humanística, agenda 2030 de desarrollo sostenible, formación docente metodológica, disciplinas de la carrera de turismo.

\section{Introduction}

The Sustainable Development Goals (SDGs) arise in response to unethical human and environmental relationships, and to face them, their main premises are projected. Sustainable development includes unlimited economic growth, social well-being increase and the educational, health and social benefits improvement. The model opposes growth based only on economic indicators, because unlimited economic activity does not lead to welfare nor at the present either in the future.

Therefore, sustainable development is a goal to take into account for designing any economic and social policy without renouncing, the economic progress in balance with social and ecological premises. Through a policy which, contain regulatory standards, it must be established the mechanisms to achieve economic growth avoiding inflationary risks. 
To protect the environment, growth must be planned harmoniously and balanced. This idea, must become a philosophy where economic growth is combined with a rational use of available resources and guarantee the human development; in order to provide decent jobs, to guarantees a health system, education and other benefits, prioritizing vulnerable sectors such as children, women, indian population, without race, gender distinction and sexual orientation.

In the specific case of tourism, the rationalization of the natural resources, which are susceptible to extinction due to their misuse and exploitation, are not excluded. To protect them, it must be incorporated the 17 goals of the 2030 Agenda into the development planning and management policies, of which, the $82 \%$ enhance human development.

In Cuba, it was created the 2030 Economic and Social Development National Plan (PNDES2030), where it was established the actions to implement the 2030 Agenda goals, which are represented by $60 \%$ in the Economic and Social Policy Guidelines of the country, making to human development one of the strategic axes to act in accordance with this plan.

Regarding to the designed actions, Higher Education in Cuba is subject to the transformations and requirements previously exposed. That is why it has designed new study plans, which propose changes to ensure the desired quality levels in the training process of future professionals and to contribute to the main professional problems resolution represented in the PNDES 2030 strategic axes and where it is established that tourism is one of the nation strategic sectors.

Under the current conditions, the students training of tourism career in Cuba demonstrate the willingness to insert themselves and meet their environment needs, the new international market and respond to the UN call for transforming our world: the 2030 Agenda for Sustainable Development. For this reason, it is opportune, for universities, to develop a strategy that gives vital importance to the professional performance able to interpret and assimilate the management techniques in different activities; with an integral conception, be holder of values and knowledge and professional skills possessor, that means, be a professional able of knowing, knowing how to do and knowing how to be, according the following action modes:

-To apply consistently the processes and projects approaches for the analytical decomposition of any professional problem that he/she faces and encourage its solution.

-To guarantee efficiency and excellence in solving professional problems.

Some problems, detected during the development of this scientific research are, that the sustainability, as strategy, is not seen by highest possible levels of actors as a way to contribute to the national and local economy, in order to acquire high satisfaction in all of tourism stakeholders (visitors, territorial business enterprises, local and national government organizations, and the local population). The tourism resources which contain and preserve the main natural, cultural, historical and social resources; are not 
identified. Being this management a method to reduce the negative impacts of tourism. The management of tourism activities systems must be focused in increasing efficiency through innovation and continuous quality improvement.

Taking into account the above ideas, the main investigation goal is to demonstrate the impact of the humanistic training on the tourism career graduate to contribute to the sustainable economic and social development.

For this, theoretical methods such as analytical-synthetic, induction-deduction; historicallogical, were applied, as well as empirical methods such as analysis and documentary review, the search and selection of information, and the observation of different actors and managers of the industry human capital to obtain information related to sustainable development behaviors and skills on the tourism career professional graduate. In addition, they were applied the observation of pre-professional training developed by the undergraduate student, as well as the work experiences demonstrated by the tourism career graduates, the systematized information about tourism professional performance endorsements at the tourism companies. Also, the official documents of the Higher Education Ministry (MES) were fundamentally analyzed as a Professional Model, Study Plan and its disciplines as well as the Teaching and Methodological Work Regulation.

\section{The Tourism Career Disciplines}

To sustainable management, human development is the main objective of growth. In the UN development program, it is proposed that development must be human-centered and economic development, social development and environmental protection are interdependent components of sustainable development. (UN, 1997: 14) And it is based on three pillars: development, sustainability and social participation.

Then, it must guarantee:

- support and solidarity worldwide taking into account that the called third world countries cannot solve environmental problems by themselves.

- a well-being that contributes to improving the personal and social life conditions.

- human development that facilitate social integration.

According to the UN, 1997; human development is

"The process of widening people's choice and the level of well-being they achieve are the core of the notion of human development. Such choice are neither finite nor static. But regardless of the level of development, the three essential choices for people are to lead a long and healthy life, to acquire knowledge and to have access to the resources needed for a decent standard of living. Human development does not end there, however. Other choices highly valued by many people, range from political, economic and social freedom to opportunities for being creative and productive and enjoying selfrespect and guaranteed human rights". pp13 
In Cuba, regarding of human development for sustainable management, the education system has been perfected at the national level, and the University has been given a definitive role, not only in the training of new generations; also in post-graduate training, with courses, in the science development and its application in the local development. Between the different specialties, in the training of tourism professionals, the fulfillment of the country's economic development objectives has been important, because it is not possible to offer quality services without training of human capital.

The main goal of the tourism career is to train a professional with comprehensive preparation, of great revolutionary sensitivity and high values of humanism and solidarity, who provide awareness skills and empathy with the environment, which allow them to manage excellent, effective and efficient services. Accepting the meaning of managing how to carry out studies and procedures to achieve an objective, it can be said that this professional is prepared, on the one hand, as a manager in tourism and travel activities and in hospitality activities, on the other, in order to attend the essential career content.

Tourism has a transdisciplinary character, with a horizontal and integrated vision of the sciences that are applied. For this reason, the career Study Plan emphasizes objectives and contents designed for its application in the elements of the tourism product: travel, destinations and hospitality companies.

For this, Plan E has been structured through the disciplines that organize the knowledge system, they are:

- The Integrator of the profession

- Tourist resources

- Tourism and Travel

- Hospitality Companies

- Applied Mathematics and Informatics

- Marxism-Leninism

- Defense Training

Integrative Discipline: it is the most important because it is the one that integrates the knowledge that students receive during the career. It is framed within the established requirements, to be considered as the exercise of the profession, and provides the graduate with a system of knowledge, habits and skills that support their comprehensive training and enables them to solve professional problems in their field of action, face the conflicts that emerge from working and propose solutions and strategic improvements in favor of the company and its stakeholders.

Through all its subjects and investigative work practice, the discipline contributes to the development of capacities related to practical scientific work and to making innovative decisions to manage and face practical situations that arise in the work environment and daily life. 
Table 1

Discipline Subjects

\begin{tabular}{lcc}
\hline The Integrator of the profession & Total hours \\
\hline 1 & DIP 1: Premises, Organization and Practice Tourism & 72 \\
2 & DIP 2 The Hospitality Process & 60 \\
3 & DIP 3 Scientific Research in Tourism & 30 \\
5 & DIP 4 Tourism Modalities & 45 \\
4 & DIP 5 Familiarization Practice & 160 \\
6 & DIP 6 GRIT Practice & 80 \\
7 & DIP 7 Tourism Ventures & 30 \\
8 & DIP 8 Enterprises Management & 600 \\
Totals & $\mathbf{1 0 7 7}$ \\
\hline
\end{tabular}

Tourism Resources Discipline: includes essential topics about the tourist resources knowledge that make the Cuban product up. Indispensable contents are addressed for understanding the tourist phenomenon from geography and the environment, universal history and the history of tourism in Cuba perspective. These contents allow the student to modify their way of appreciating the natural historical heritage, to understand the origins of the territorial tourist attraction in order to promote the development of sustainable tourism. The knowledge provided by the discipline allows to complement those structured in the Integrative and Tourism and Travel disciplines, by introducing basic concepts to understand theoretical, methodological and practically the objective bases on which tourism is developed. It provides to the student with the theoretical foundations to make them aware of the rational use of resources and the conservation of natural and cultural heritage.

Table 2

Discipline Subjects

\begin{tabular}{llc}
\hline Tourism Resources Discipline & Total hours \\
\hline 1 & Universal History Panorama & 45 \\
2 & Cuba History & 52 \\
3 & Tourist Geography and Nature Heritage & 65 \\
4 & Cultural Heritage & 52 \\
5 & Tourism History in Cuba & 30 \\
Totals & $\mathbf{2 4 4}$ \\
\hline
\end{tabular}

Tourism and Travel Discipline: covers the study of two of the three types of tourism products: travel tourism products and territorial tourism products. In charge of providing communication and information management techniques, vital for the development of travel and tourism; the essential knowledge about destination management, and the principles and actions of the commercialization process, which allows the tourist flow from to Cuba destination. 
It is a discipline that complements the acquisition of knowledge in an integrated manner and addresses essential elements in the mode of tourism operation, through mastering the necessary fundamentals, to ensure efficient management of tourism activity at all levels of travel tourism products.

Table 3

Discipline Subjects

\begin{tabular}{llc}
\hline Disciplina Turismo y Viajes & Total hours \\
\hline 1 & Communication Process & 30 \\
2 & Information Resources Management in Tourism (GRIT) & 26 \\
3 & Tourist Destination Management & 30 \\
4 & Economy & 20 \\
5 & Marketing & 60 \\
6 & Tourism Rights & 20 \\
7 & Tourism Transport Management & 39 \\
8 & Travel Agency Management & 40 \\
9 & Guide Techniques & 40 \\
Totals & $\mathbf{3 0 5}$ \\
\hline
\end{tabular}

Hospitality Companies Discipline: provides a system of knowledge, methods, techniques that can be used in the execution of functions related to management in the different functional areas of hospitality organizations and companies, providing the graduate the theoretical - practical preparation and an understanding of the need to apply these techniques in solving problems in mentioned entities, to achieve quality and excellence in business management.

Table 4

Discipline Subjects

\begin{tabular}{llc}
\hline Hospitality Companies Discipline & Total hours \\
\hline 1 & Strategy and Management & 65 \\
2 & Accounting & 60 \\
3 & Human Resource Management & 40 \\
4 & Quality Management & 20 \\
5 & Project Management & 39 \\
6 & Accommodation Management & 78 \\
7 & Restaurants Management & 65 \\
8 & Products Commercialization & 40 \\
9 & Leisure and Recreation Management & 50 \\
Totals & $\mathbf{4 5 7}$ \\
\hline
\end{tabular}

Marxism and History Discipline: allows to understand and value the theoretical assumptions of Marxism for the contemporary socio-political, economic, ideological and cultural transformation, with emphasis on the Cuban reality, therefore, it has a general 
cognitive role to apply it in the objectives of tourism development, as well as strengthening the ideological understanding of the revolutionary principles of the nation.

Table 5

Discipline Subjects

\begin{tabular}{llc}
\hline Marxism and History Discipline & Total Hours \\
\hline 1 & Philosophy and Society & 48 \\
2 & Politic Economic I & 45 \\
3 & Politic Economic II & 30 \\
4 & Sociopolitical Theory & 39 \\
Totals & $\mathbf{1 6 2}$ \\
\hline
\end{tabular}

Defense Training Discipline: promotes preparation for the safeguarding of heritage and the defense of the principles that govern the political, economic and social system of the country. It encourages the creation of ethical and moral values that support the revolutionary guidelines of the nation. In connection with the mentioned disciplines, they train the integral professional for the defense of the Cuban revolution.

Table 6

Discipline Subjects

\begin{tabular}{lc}
\hline Defense Training Discipline & Total Hours \\
\hline $1 \quad$ Nacional Safety & 40 \\
2 Nacional Defense & 30 \\
Totals & $\mathbf{7 0}$ \\
\hline
\end{tabular}

Therefore, the disciplines promote the improvement, education and human development of the tourism professional; through an organized methodological work that allows the preparation of teachers to integrate knowledge based on the profile of the 21 st century student, and the reinforcement of their ethical and moral values, taking into account the development objectives of the local tourism sector and the objectives of sustainable economic and social development of the country.

\section{The role of the Tourism Career professors}

It is responsibility of those who are in charge of the disciplines to prepare professors to teach each content through the subjects, to ensure an adequate organization of the content that enables the fulfillment of the objectives and skills, avoiding repetition of subjects between different disciplines. All of that, should promote the intra, inter and transdisciplinary development that allows the success of the career objectives, achieving the main role of students in the educational teaching process, as well as the information technologies and communications use, in order to analyze the application results of the discipline program and to measures the sustainable development training of the future professional in the tourism sector, to assume social and ethical responsibilities, ensure equal empowerment and specialization through education. 
Train and develop skills in students according to the rigor and excellence of the sector, provide the tourism industry with human potential in according to the science and technology development, and provide them attitudes and values that allow them to know how to be and know how to do. Help them to create awareness of the need to manage and develop researches that contribute to solve the sector scientific problems, promoting sustainable tourism development from its fundamental premises: efficient economic management, environmental management, and sociocultural management.

Through studies of how climate change affects tourist seasons, how to reduce the energy and drinking water levels consumption by accommodation, leisure and restaurant companies, how to design internal policies in an organization that favor gender equality, social inclusion, human and professional improvement, how to implement a strategy for the evaluation, external certification and improvements of sustainability in the organizations management, according to the 2030 agenda.

On the career, it is nowadays working on sustainable development empowerment, from the teacher preparation due to the existence of inefficiencies for developing the knowledge and skills for sustainable management and its implementation in the sector by the teachers of the tourism department. Where approximately $63 \%$ of all teachers are recent graduates with little experience in teaching-methodological work.

Therefore, for the teacher training and preparation, a methodological work system has been internally organized in order to be prepared to fulfill their role in the professional and comprehensive improvement of the tourism student. For this, they were taken into account the provisions of the Constitution of the Republic of Cuba on sustainable development and the Life Task for confronting climate change. And aiming to the deficiencies that the different companies of the Tourism Ministry (MINTUR) present regarding that, the following methodological teaching activities were designed, contained in the Methodological Teaching Work Regulations, based on the creation of skills in the teacher to impart the contents of the disciplines promoting sustainable tourism development.

The methodological teaching meeting has been designed twice a year, one each teaching period in order to facilitate the analysis, debate and decision-making about issues related to the educational teaching process for its better development, and the analysis of the essential contents based on the disciplines guiding role and their guidelines in terms to provide feedback and decide according to the educational teaching process for its optimal development in this case, in favor of the management of the SDGs and PNDES 2030 and their implementation by teachers in each of the disciplines. Both meetings are led by the head of the department and the head of methodological teaching work.

Three methodological classes have been designed, with a quarterly period to guide and instruct methodologically the teachers and favor their preparation for the development of the educational teaching process, on the contents of the disciplines 'subjects that respond to the progress of skills and values from the instruction for a sustainable management, on the elaboration and fulfillment of the educational teaching process objectives, the support 
of values through classes and work training, depending not only on the contents of the disciplines and subjects but also on the problem declared by the tourist company.

Two open classes have been structured to guide teachers on the development and fulfillment of the class objectives, about the use of the classes contents and from the instruction how to comply with the orientations and disciplines objectives.

Five certification classes were designed, in correspondence with the number of recently graduated teachers, to verify their preparation and compliance with what was demonstrated in previous activities and to promote the improvement of the methodological teaching work of the teachers, demonstrating the appropriate method for instructing from the content in connection with the objectives of the 2030 Agenda.

Two methodological teaching workshops have been developed, according to the methodological teaching meetings. In order to debate the related experiences and the results obtained in the teaching process as well as in the visits to the students' work trainings. Taking into account, the implementation of the actions previously exposed and to listen to suggestions of new activities that they feel are necessary for their training that could allow the achievement of training a student according to the desired model and the demands of the tourism company. In addition, deficiencies of the previous period are discussed and new actions are proposed and alternatives to perfect it.

Also, two Sustainable Management in Tourism courses were designed, one of them theoretical and the other about training where graduates, teachers, workers from government and private sector, have the possibility of learning and deepening not only since the theory but also in practice on this management model. A Diploma on Tourism Management was designed. A hard job is being done on the development of a Sustainable Management Project that will contribute with new actions to develop a sustainable culture in the Matanzas province tourism sector, all of that due to its importance in the country's tourism development.

\section{Impact of humanistic training on the tourism future professional}

The Tourism career also works in coordination with the tourism companies, through the combination of pre-professional training and the development of teaching and scientific research activities in different work settings. Where, the students perform and carry out research, data collection and interviews with different actors of the tourist activity, in order to contribute to the transformation of the sector in correspondence with the new trends in the international market.

It prepares the undergraduate student to assume responsibilities as process managers such as commercial, marketing and sales managers, responsible for corporate image and destinations, communication managers, promoters and heritage interpreters, coordinators and managers of travels and service packages tourism, evaluators of administrative and environmental quality, and so forth. 
Therefore, to assume such as roles, it is necessary to have a vocation and correct training in higher education centers; not only to acquire skills, abilities and techniques of each profession, but also to respond to certain tourist activity situations in a sustainable way and transmit the company's moral and ethical values in each of the responsibilities, in order to build a competent solidarity and spiritual environment and professional selfrealization.

The human attitude represented by the contents of each of the disciplines described in the students of the tourism career, allows them, during their pre-professional practice exercise or once they have graduated from higher education;

- the attention skills to understand a guest's main need, understand what it is trying to express, find common interest, reach agreements and negotiate;

- to promotes the acquisition of interaction and social skills to thank, exchange interests, approach new guests, get experience from them, join business groups easily, be adaptive to the changes, correct mistakes, have the capacity for conviction and assertiveness;

- awakens feelings to others in the future professional, which favors understanding and empathy about possible difficulties faced by a certain visitor or the companies themselves, fosters concern and motivates the proposal of solutions;

- generates agility to combat aggressive action through teamwork, the expression of new ideas with respect to experience co-workers, through control of their individual character and the resolution of unforeseen events in a peaceful and strategic manner;

- encourages communication in order to support and ally diplomatically and peacefully with the main competitors without resentment, have their own flexible and safe decision for the common good, the company and the stakeholders, think before communicating an idea;

- Help in the strategic planning process by analyzing the causes of a certain problem, by focusing on the essential objectives of the corporation, which provide economic, social and environmental satisfaction, through the search of updated information;

- develops the capacity for leadership and emotional intelligence in the student or graduate, and a transmitter and defender of the culture, traditions and idiosyncrasies.

The practice of humanistic training and soft skills is important since it avoids the formation of simple and closed points of view, expands the human mind towards its own personal improvement and expansion of capacities in favor of environmental conservation, human development; and therefore, the economic and social development of the nation. 


\section{Conclusions}

- The development of methodological teaching activities allowed to deepen the preparation of graduates who work as teachers in the Tourism Bachelor career, in order they are able to adequately train the tourism professional, providing them with a system of knowledge, skills, values that they are transformed into attitudes and qualities that make it possible to redirect work in the tourism sector towards sustainable management.

- The methodological training of the Tourism Bachelor disciplines, promote the improvement, education and human development of the future professional; they reinforce their ethical and moral values, taking into account the development strategies of the local tourism sector and the economic and social development objectives of the country.

- The practice of a humanistic training at the university favors the improvement of skills, values, capacities for an adequate management of the knowledge of the graduates and in its implementation in the modes of action in the company, providing them with habits for knowledge management, the search for solutions from science to the problems that arise by offering solutions, contributing to sustainable management in the development of tourism with performances in favor of environmental conservation, human development; and therefore, the economic and social development of the nation.

\section{Bibliographic reference}

Acosta Chongo, Y., Vázquez Cedeñom, S., \& López Bastida, E. J. (2018). Estrategia curricular de formación ambiental para la carrera de Ingeniería Mecánica. Revista Científica de la Universidad de Cienfuegos, Volumen 10 ( Número 4), 192-198. Retrieved from http://rus.ucf.edu.cu/index.php/rus

Alarcón, R. (2013). Hacia un mayor impacto de la educación superior en el desarrollo local. Revista cubana de Gestión Empresarial: Nueva empresa. Universidad y desarrollo local. Empresa de Gestión del conocimiento y tecnología. GECYT, Vol. 9(No. 3), p. 8.

Albertos, J. E., Amilburu, M. G., Arbués, E., Antonio, A. J., \& al, e. (2018). Educación Y Capacidades: Hacia Un Nuevo Enfoque Del Desarrollo Humano. (J. A. Ibáñez Martín, \& J. L. Fuentes, Eds.) Madrid: Editorial DYKINSON. Retrieved from www.dykinson.com/quienes_somos

Alean Pico, A., Del Río Cortina, J., Simancas Trujillo, R., \& Rodríguez Arias, C. (2017). ¿El Emprendimiento como Estrategia para el Desarrollo Humano y Social? SABER, CIENCIA Y Libertad, Vol. 12(No.1), Págs. 107-123. doi:DOI: https://doi.org/10.18041/2382-3240/saber.2017v12n1.1470 
Alpizar Santana, M. (2018). Resultados y desafíos de la universidad cubana en el desarrollo humano sostenible. Revista Estrategia y Gestión Universitaria, Vol. 6(No. 1), Pág. 172-188. Retrieved from http://revistas.unica.cu

Aznar Mínguet, P., \& Barrón Ruiz, Á. (2017). El Desarrollo Humano Sostenible: Un Compromiso Educativo. Teoría de la Educación. Revista Interuniversitaria 29, 1, pp. 25-53. doi:DOI: http://dx.doi.org/10.14201/teoredu20172912553

Boni, A., Belda-Miquel, S., \& Pellicer-Sifres, V. (2018). Innovación transformadora. Propuestas desde la innovación social colectiva para el desarrollo humano. Recerca. Revista de Pensament $i$ Anàlisi, 23, pp. 67-94. doi:doi: http://dx.doi.org/10.6035/Recerca.2018.23.4

Díaz, P., \& T., A. (2017). El derecho humano a un desarrollo sostenible en solidaridad con la Naturaleza. Revista Iberoamericana de Bioética $\left(\mathrm{n}^{\circ}\right.$ 04), 01-11. doi:DOI: 10.14422/rib.i04.y2017.004

Espinach Rueda, M. (2017). Agenda 2030 del desarrollo sostenible promulgada por la organización de las naciones unidas: caso costa rica. Ágora de heterodoxias Vol. 3, $N^{\circ} 2$, pp. 50-67.

Fuertes Grábalos, E., Plou Lafuente, P., \& Gómez Bahillo, C. (2017). Desarrollo humano desde la perspectiva del crecimiento. Revista de Ciencias Sociales Vol. XXIII, No. 4, pp. 81-97.

García-Lirios, C. (2019). Dimensiones de la teoría del desarrollo humano. Ehquidad International Welfare Policies and Social Work Journal 11, 27-54. doi:doi:10.15257/ehquidad.2019.0002

León Pupo, N. I., Castellanos Domínguez, M. I., Curra Sosa, D., Cruz Ramírez, M., \& Rodríguez Palma, M. I. (2019). Investigación en la Universidad de Holguín: compromiso con la Agenda 2030 para el desarrollo sostenible. Revista Electrónica “Actualidades Investigativas en Educación”, Volumen 19(Número 1), pp. 1-28. doi:DOI 10.15517/aie.v19i1.35699

Monge Ortiz, J. A. (2020). El propósito de la formación humanista en la Universidad de Costa Rica del siglo XXI. Revista Estudios, 1-15.

Moya Otero, J., \& Hernández Ortega, J. (2020). Una metamorfosis educativa para alcanzar un desarrollo humano sostenible. Revista de Currículum y formación del profesorado. VOL.24, No3. doi:DOI: 10.30827/profesorado.v24i3.15971

Patiño Domínguez, H., \& López Calva, J. M. (2017). ¿Qué hacen los docentes de excelencia? Claves para la formación humanista en la universidad. Perfiles Educativos vol. XXXIX, núm. 155, 1-7. 
PEDRAJAS, M. (2017). La Última Milla: Los desafíos éticos de la pobreza extrema y la vulnerabilidad en la Agenda 2030 para el Desarrollo Sostenible de Naciones Unidas. VERITAS, $N^{\circ} 37,79-96$.

Pérez Velázquez, J. E., \& Santos Abreu, I. (2017). La educación ambiental para el desarrollo sostenible en la formación del profesional en las escuelas pedagógicas. VARONA, núm. esp., pp. 1-11. Retrieved from http://www.redalyc.org/articulo.oa?id=360657468019

Rosales, M. (2017). EL DESARROLLO HUMANO: UNA PROPUESTA PARA SU MEDICIÓN. Aldea Mundo, vol. 22, núm. 43, pp. 65-75.

Tezanos Vázquez, S. (2019). Hacia una clasificación del desarrollo sostenible compatible con los ODS y el "desarrollo en transición". AMÉRICA LATINA Y EL CARIBE EN LA AGENDA 2030, 1-24. Retrieved from https://unican.academia.edu/SergioTezanosVazquez

TEZANOS, S. (2017). Agenda 2030 para el Desarrollo Sostenible: 7 riesgos, 7 oportunidades. El portal de la cooperación iberoamericana, 1-4.

UN. (1997). Human Development Report. New York: UNDP.

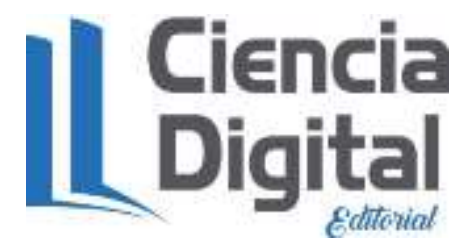




\section{PARA CITAR EL ARTÍCULO INDEXADO.}

Tanyara Sánchez, J., Jiménez Valero, B., Caridad Alina, J. A., \& Velastegui Lopez, E. (2021). Impact of humanistic training on the tourism future professional . Ciencia Digital, 5(4), 114-128. https://doi.org/10.33262/cienciadigital.v5i4.1903

\section{Liencia}

El artículo que se publica es de exclusiva responsabilidad de los autores y no necesariamente reflejan el pensamiento de la Revista Ciencia Digital.

El artículo queda en propiedad de la revista y, por tanto, su publicación parcial y/o total en otro medio tiene que ser autorizado por el director de la Revista Ciencia Digital.
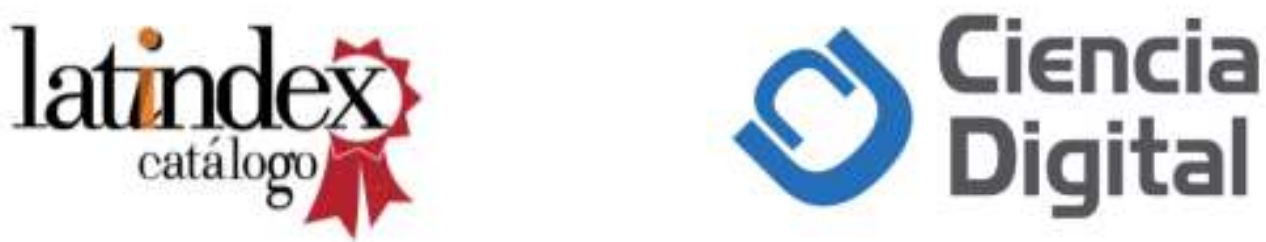